\title{
INTUITION AND MANAGERIAL DECISION-MAKING ${ }^{1}$
}

\author{
VERONIKA GIGALOVÁ
}

\begin{abstract}
The study examines new possibilities for recognising and understanding intuitive managerial decision-making, which is increasingly discussed in relation to the theory of management. Managers make decisions in organisations which have been undergoing transformation related to societal changes. Managerial decision-making is still understood as a purely rational action. Let us suppose that managers are able to entirely rationally calculate inputs and outputs, or the consequences, of their actions, and always do so to achieve set goals. Managers are expected to decide quickly, and this increases the probability of errors occurring. Therefore, intuition derived from knowledge, experience and emotions is now taking precedence over rationality.
\end{abstract}

Key words: decision-making; rationality; bounded rationality; intuition.

\section{Introduction}

The aim of the paper is to show how managerial decision-making can be explored through metaphor. It is an attempt to explain how this approach can include knowledge, experience, but also emotions. These three categories are reflected in the management decisionmaking rational, but the main one is intuitive. Therefore, the method is focused on intuitive decision-making. I do not consider rational analytical decision-making to be marginal; quite the contrary. But rational managerial decision-making can be explored using many more precise methodological tools. Intuitive decision-making is more hidden and therefore any methodological input can potentially extend the view of managerial decision-making. Managers make decisions in organisations that have been undergoing significant change in relation to societal changes. There are many means of exercising power available to them, including the decision-making power that enables them to decide key issues concerning company direction. Decision-making by managers in organisations is still understood mostly as a purely rational activity. We suppose that managers are able to deliberately calculate inputs and outputs, or the outcomes of their actions, and always do so in order to achieve set goals. However, these days managers are expected to decide quickly,

1 This study was written within the Framework of the project "Social Sciences 2016" (IGA_ FF_2016_049) funded by the Palacky University Olomouc.

DE GRUYTER

(C) Institute for Research in Social Communication, Slovak Academy of Sciences 
which implies a risk that more errors will be made. Intuition stemming from knowledge, experience and emotions is thus taking over from rationality. But how are we to examine this phenomenon? This is the central concern of this article, and the research and results are described here. I was interested firstly in the changing perspective on rationality in relation to decision-making among managers in an organisation, and on the nature of this change and the introduction of intuition into the decision-making process. I therefore looked for a tool suitable for examining the nature of managerial decision-making. From a cognitive linguistics perspective, language appears to be a suitable means of exploring human thinking, and it is a metaphorical system used by managers when rationalising their decisions and is a source of data for expanding the knowledge base on managerial decision-making.

\section{Bounded rationality as an impulse for the use of intuition}

Managers cannot foresee all the consequences of their actions because the consequences belong to the future and we can only imagine them. Rational behaviour implies that we consider all possible alternatives. However, it can be hard to think of alternatives when the problems are so complex. Therefore, according to Simon (1976), decision-making must be understood within the context of limited rationality. Our beliefs, expectations and complete objectivity often come into our decisions, and logic is merely an economic idea (Simon, 1986, pp. 209-211). Yet, according to Robbins and Coulters, a good manager is expected to make a comprehensive rational decision. This involves identifying the problem, considering the alternatives, collecting information and acting decisively and deliberately. In reality, however, managers usually make simplified decisions and Robbins and Coulter state that this leads to limited rationality (Robbins \& Coulter, 2004, p. 156). According to Simon, there are several assumptions concerning limited rationality. They include (1) incompleteness of knowledge, (2) difficult predictions, and (3) the extent of behaviour (Simon, 1976, pp. 9497). Managers usually make decisions within a limited rationality because obtaining all the information required is difficult, often impossible. To anticipate the consequences of their choices and to recognise all the variants of behaviour so that they can rationally decide on them is difficult in turbulent conditions.

A model of managerial decision-making is emerging in management, sometimes called the intuitive model, based on Simon's theory of limited rationality and the knowledge obtained around it. The concept of cognitive turnover in psychology has transformed views of cognitive processes.

That decision-making is based on rationality has been contested by, for example, Herbert Simon and Robert K. Merton. In Simon's explicit theory of the bounded rationality of human action, the basic thesis is that in practical life people do not seek optimal solutions to the problem they are confronted with. Rather, they are generally satisfied with the first satisfactory solution they find (Simon, 1979). Their calculations are much less ambitious and much more pragmatic. As soon as they reach an acceptable threshold of satisfaction, they move on to the next step without retrospectively debating optimal solutions (Simon, 1979). People's intellectual capacities are thus bounded in relation to the considerable complexity of the problem they have to solve. 
Merton defines the unintended consequences of a purposeful action. Human action (including that of managers) takes place within an organisation system. At the same time, it is bounded by this system and isolated from the outer social environment. Although there is no question that the outer social environment significantly influences the organisation system, it is not possible to determine all the links with the outer environment. Therefore, there is no way of estimating or recognising every possible consequence of their decision. This shifts managerial decision-making away from economics and towards being a social phenomenon (Merton, 2007). Approaches that have had a key influence on theories of change in managerial decision-making are those of Gerd Gigerenzer, Gary Klein, and Daniel Kahneman.

I have included Gigerenzer's theory of fast and frugal heuristics only because it is frequently used in managerial decision-making processes. As Gigerenzer states, "typical decision-making in organisations includes heuristics because the conditions required by rational models of decision-making are seldom useful in the precarious world" (Gigerenzer \& Gaissmaier, 2011, p. 474). Gigerenzer considers heuristics to be a good basic problemsolving tool owing to their simplicity and the speed at which they can be used to react to the challenges of an ever-changing environment. The naturalistic approach to decision-making is even more progressive and emphasises the specific nature of problem-solving strategies. Gigerenzer considers intuition to be the result of expert knowledge (Klein, 2009). However, Kahneman states that the significance of intuition in decision-making is overestimated, and he suggests that frugal heuristics may be distorted by intuition and impressions that he considers to be influenced by the unstable environment. The changeability of the environment leads to inconsistency in judgement (Kahneman, 2012). In order to understand how theories of decision-making have developed, it is essential to consider Gigerenzer's theory of the adaptive toolbox.

The theory of the adaptive toolbox combines findings of Simon's theory of bounded rationality and findings of Darwin's theory, and also aspects from long-time research. The adaptive toolbox is a modular mind system composed of heuristics, their building blocks, and a developed capacity (Gigerenzer, 2008, p. 20). Its components include social norms, imitations, and emotions established in cognitive building blocks (Gigerenzer \& Selten, 2002, p. 48). Simon's theory can be contrasted with theories of logic and optimisation since it postulates a certain narrowness of the human mind. The mind not only does not have the capacity to seek out the optimal solution (Gigerenzer, 2008), but according to Gigerenzer, there is no optimal solution or it is less accurate where there are changes in the nature of the environment, be it physical or social (Gigerenzer \& Selten, 2002).

Before delving into Gigerenzer's definition of heuristics, it is essential to mention that this term is used in various academic disciplines with their own theories and definitions of heuristics. Among the definitions of heuristics relevant to decision-making and judgement forming is that by Kahneman, for example, which states that heuristics is a simple procedure that "helps to find adequate, though often inaccurate answers to difficult questions" (Kahneman, 2012, p. 109). Here we can see Kahneman's distrust of intuition. Gigerenzer's perspective on heuristics differs from Kahneman's. For Gigerenzer heuristics is a decisionmaking strategy that "ignores a portion of information in order to decide faster, more simply and/or more accurately than in case of more complex methods" (Gigerenzer \& Gaissmaier, 
2011, p. 454). Kahneman's view of heuristics is rather negative since he presents heuristics in relation to the mistakes it leads to (Kahneman, 2012). However, Gigerenzer praises heuristics for its frugality and speed.

He sees fast and frugal heuristics as consisting of several building blocks that follow certain rules. We usually use these rules to solve new and complex situations, which helps us adapt to the ever-changing environment (Gigerenzer, 2008, p. 25). Gigerenzer determines search rules that determine the direction of search until a stimulus that evaluates alternative possibilities is found. A fixed stopping rule then appears. As soon as the search is stopped and a potential problem-solving means is found, a decision rule has to be used to select an option that does not require complex calculations involving further effort. According to Gigerenzer, the search is not stopped on the basis of the cognitive evaluation of the situation alone. The emphasis is also on emotions and social imitation. They are, in his opinion, much more effective tools, enabling decisions to be made within a limited time and with limited resources (Gigerenzer \& Selten, 2002). "Heuristics is neither good nor bad, neither rational nor irrational; its exactitude depends on the structure of the environment (ecological rationality)" (Gigerenzer \& Gaissmaier, 2011, p. 474). Therefore, the functioning of fast and frugal heuristics is reliant upon the structure of the environment in which they take place. Thus, from Gigerenzer's perspective, they operate within ecological rationality (Gigerenzer, 2002, 2008; Gigerenzer \& Gaissmaier, 2011).

\section{The emotional factor and intuitive decision-making process}

It is not only knowledge and experience that influence the intuitive decision-making process. Both this and rational decision-making are influenced by emotions. Simon was one of the first theoreticians to defend the idea that emotions enter the intuitive decisionmaking process as well (Simon, 1987a). However, he considered them to be the source of irrational decisions; this position was not exceptional in the past (e.g. Young, 1961). Just in the past few decades one can encounter positive reactions to the idea that emotions influence the decision-making process; this is related to developments in the research. One of the first consistent and thus far non-refuted theories that examines emotions in intuitive decision-making is the somatic marker hypothesis by Antonio Damasio. He highlights the influence of the biological mechanisms that are part of the intuitive decision-making process.

In order to understand his theory, one has to view emotions as being divided into primary or secondary emotions. Damasio argues that the stimuli that are evolutionarily encoded in our consciousness trigger are primary emotions. Secondary emotions are more complex. They manifest themselves in the same ways as primary emotions, but are triggered by different stimuli. Damasio states that secondary stimuli are created "when we become conscious of emotions and create systematic connections between categories of objects and situations on the one hand and primary emotions on the other hand" (Damasio, 2000, p. 122). In other words, primary emotions originate from innate reactions to certain stimuli, and they are often associated with the self-preservation instinct. Secondary emotions form during the processes of creating and learning through the associations that we construct between kinds of objects and primary emotions. 
If we accept the idea that automatic pre-selection takes places through somatic markers, or feelings as the results of secondary emotions, then we also have to admit that these emotions lead to the creation of possibilities of solution that we consider in decisionmaking rationally or intuitively. Löwenstein and Lerner focus on the concrete ways in which emotions can specifically influence the intuitive decision-making process. The essential point of their theory is that the classification of emotions as immediate and anticipated. The criterion is the influence emotions have on the decision-making process in time.

According to Löwenstein and Lerner, anticipated emotions relate to predictions about the emotional consequences of the decision-making outcome (Löwenstein \& Lerner, 2003, pp. 621-626). Thus, they are premises of future emotions. Immediate emotions reflect the combination of effects of emotions triggered when considering the consequences of the decision itself (preliminary influences) and of those stemming from factors unrelated to decision-making (random influences) (Löwenstein \& Lerner 2003, pp. 626-633). Therefore, this theory implies that anticipated and immediate emotions influence the decision-making process itself and the outcomes. Immediate emotions can equally have an effect in the preintuitive phase of the decision-making process and that will be examined below.

I consider the theory of anticipated and immediate emotions to be essential to this work mainly because of the key aspect of this theory: the role the power of immediate emotions plays in the decision-making process (Löwenstein \& Lerner, 2003). In other words, the more intense immediate emotions are, the more they are involved in the decision-making process. This reduces the probability that rational models based on the rational evaluation of possibilities and optimisation will be used.

\section{The importance of knowledge, experience and emotions in intuitive decision-making}

This theory, like Gigerenzer's theory of fast and frugal heuristics, is based on the concept of bounded rationality. Gary Klein, who examines the decision-making process within the complex structure of the world, is probably the most important proponent of the naturalistic concept. According to Klein and Klinger, the complex structure of the world leads to dynamic and ever-changing conditions, wrongly defined or structured tasks, time pressures, and affects the experience of the decision-makers (Klein \& Klinger, 1991, p. 16). One of the main objectives in naturalistic decision-making theory is the demystification of intuition by identifying the stimuli used by experts when making decisions even if these stimuli are based on tacit knowledge and an expert describes them with a difficulty (Kahneman \& Klein, 2009, p. 516). Here, Klein and Kahneman point out that the term "intuition" is often used in different ways and the task is to establish the key factors affecting the use of intuition. Klein considers tacit knowledge to be the key factor (Klein, 2015).

Tacit knowledge, Klein states, is hard to recognise and often inaccessible to our consciousness. Judgements and decisions based on this type of knowledge appear intuitively as soon as we create patterns of action where the content will be judgements and decisions. Given that patterns of action result from experience, they are specific (Klein, 2013, pp. 164166). In other words this theory states that everyone has a different type of experience, and we create specific schemata of action based on that experience. These schemata are created intuitively based on our experience and are then used through intuition (Klein, 1998). 
Klein defines intuition as "a way in which we apply our past experience in current decision-making" (Klein, 2003, p. 35). One can consider it the ability to classify a situation and to choose a suitable response based on remembered schemata. Intuition can be enhanced by offering a wider experiential basis which allows people (or managers) to build better tacit knowledge, such as perceptual abilities, and richer mental models to help experts to make better decisions. The more we strengthen intuition, the better our expertise (Klein, 2013, p. 166). To put it simply, gaining experience leads to the creation of mental schemata and also builds up tacit knowledge; both of which enhance our intuition. In his Recognition-Primed model (RPD) Klein describes the way in which the experience gained is used in the complex structure of the world.

Klein's research demonstrated that experts make decisions based on their experience (Klein, 1993; Klein, 2013; Klein \& Klinger, 1991). From this it follows that decisionmaking is a long-term cyclical process through which an expert knowledge set is created; this knowledge set enables experts to make fast decisions. According to Klein the thing that makes decision-makers experts is their ability to apply conceptual differentiation, recognise formulae, source rich mental models, and assess typicality (Klein, 2009).

On this view intuition is seen as a source of better solutions than the optimisation model can offer, because these decisions stem from expert knowledge and experience, enabling the identification of the key moments in a situation. This expert knowledge and experience is transformed into tacit knowledge that creates the mental models and schemata of action. The models are then applied to solve the typical situations in which experts find themselves the influence of intuition on decision-making is not seen as positive in all approaches.

Although studying intuition in relation to decision-making has become important, not all theories see intuition as a precondition for better decision-making strategies than that provided by the analytical and rational model. David Kahneman, who examines the distortions affecting good decision-making, falls into this category. His view of intuition is based on Simon's definition of intuition, which states that "a situation provides a clue, and this clue gives experts access to information stored in their memory; this information gives an answer. Intuition is not more or less than knowledge of something" (Simon, 1992, p. 155). Simon points out that one can only rely entirely on intuition in moments one has already experienced in the past. Kahneman agrees with this when he states that "intuition cannot be trusted if it does not refer to a stable rule in the environment" (Kahneman, 2012, p. 259). He seeks to emphasise that one can rely on intuition even when the situation becomes unpredictable. This is also affirmed in an article by Kahneman and Tversky where they state that people's decisions are often based on heuristics. Heuristics facilitate cognitive processes and catalyse the decision-making process, but mistakes can also be made because of them (Tversky \& Kahneman, 1974, p. 1124). These errors can be tolerated in everyday judgements but not in the intuitive judgements of professionals (Kahneman, 2012; Tversky \& Kahneman, 1974).

This view on intuition is rather a sceptical one. It sees it as the consequence of making unconscious judgements which are not supported by real evidence. This causes errors to be made. Decisions should be made based on analytical and optimising models, which can help avoid intuition-based errors.

In order to examine the overall picture of the decision-making process used by managers, we need to look at the characterisation of differences in analytical (rational) and non- 
analytical (intuitive) decision-making described by Robin Hogarth (2002) in his model of relative and analytical decision-making.

Hogarth's model is based on Epstein's cognitive-experiential self-theory, which assumes there are two information processing systems-experiential and rational. Epstein says that the experiential system is "a raw system that automatically, quickly, and effortlessly processes information," (Epstein, 1994, p. 715) whereas the rational one is "an intentional (...) abstract system (...) capable of operating a high level of abstraction" (p. 715). He further describes the rational system as being analytical, verbal, and rational (p. 710). Thus, one can conclude that the experiential system takes place within the unconscious, and is influenced by emotions and intuitions, whereas the rational one is based on conscious, rational judgement and the evaluation of strategies in decision-making. By distinguishing between the two systems, Epstein highlights the fact that people can have intuitive knowledge that they use without consciously analysing it. He considers the experiential system to be better and more effective than the rational one (Epstein, 1994, pp. 719-720). Although Hogarth's theory (2002) is rooted within these theoretical bases, he does not agree with them entirely, and his disagreement is formulated by the creation of a model that introduces criteria that determine the moments when intuition is used more effectively than analytical (or, in Epstein's words, rational) decisions. Knowledge and experience influence rational decision-making as well as intuitive decision-making. When making conscious and rational decisions, information is used intentionally and elaborated on and analysed at the same time. This process is, however, slower than intuitive, unconscious decision-making. This is corroborated by research by Seymour Epstein, who differentiated between two ways of information processing - rational and experiential. Rational information processing can seem faultless on first examination. However, given the aforementioned limited rationality and unintended outcomes, it is obvious that it is unrealistic to assume a problem can be analysed purely rationally. Therefore, realistic processing can be erroneous. According to Epstein, it is slower than experiential information processing, which is also required for intuitive decisionmaking. The speed of decision-making is important but so is adequacy (Epstein, 1998).

As I have already mentioned, Hogarth's theory is based on Epstein's categorisation of information processing as experiential and rational. Hogarth adapts these terms for his theory of decision-making, stating that people make decisions with the help of two systems associated with tacit (or intuitive) and intentional (or analytical) thinking. Hogarth describes the tacit system as one actuated by unconscious thinking to which one has only limited access (Hogarth, 2002, p. 5). This system is activated effortlessly with the help of a stimulus that appears in the environment, whereas intentional thinking is controlled more by cognitive processes (Hogarth, 2002, p. 9). This means that cognitive effort is necessarily part of analytical thinking. While tacit judgements are made unconsciously, intuitively.

Hogarth considers two factors that could affect the application of correct and exact formula: the presentation and the complexity of a problem. From this follows the basic assumption that the knowledge and ability of a person to apply the exact and correct formula is conditional on the level of the analytical complexity of a given task (Hogarth, 2002, p. 32). He refers to the analytical complexity of a task as the task's complexity. The task's complexity can be demonstrated in, for example, the variety of solutions (Hogarth, 2002, p. 32). In other words, the greater the analytical complexity, the more demanding it is for a 
person to apply the correct formula obtained via analytical thinking. It could also be said that the greater the analytical complexity of a task, the more probable it is that tacit, or intuitive, thinking would be more successful. Therefore, in which situations can one rely on intuition and when is it preferable to use an analytical solution and cognitive evaluation of the situation? This is examined in the following model.

Hogarth's theory offers a simplified model that can be used as a guide for evaluating the use of intuition in the decision-making process. He considers intuitive reactions or decisions to be the result of learning. These reactions are expressed unconsciously and unintentionally, without the exertion of cognitive effort. Whether an intuitive reaction is correct is decided by the analytical complexity of the environment and by the mistake dimensions that are the immanent content of tacit processes. It is still unclear though what this implies for managerial decision-making. The reason is that it is an inner process involving thinking, attributing meaning and ordering values, which all stem from knowledge, experience and emotions. It is necessary to find a way of understanding the entire process or at least part of it. We could then obtain a clearer image of managerial decision-making. Knowledge, experience and emotions are the key elements influencing the inner process of intuition. The narrowing is deliberate and this reduction should lead to the creation of a synoptic or a more synoptic definition of intuition that can be used to identify and describe intuitive managerial decision-making. Why these three categories? The following should serve as an explanation.

\section{Intuition}

The research on the possibilities of using intuition in managerial decision-making processes has grown substantially (Klein, 2003; Hogarth, 2001; Shapiro \& Spence, 1997; Dane \& Pratt, 2007; Kahneman, 2012; Chase \& Simon, 1973). There is an element of mistrust regarding research on intuition, related to the uncertainties over the definition of intuition. It is true that this concept is not clearly defined in the literature, perhaps because it is understood differently in psychology, philosophy and theories of managerial decision-making.

One of the first theoreticians to examine intuition in managerial decision-making was De Groot who published a study in 1946 in which he examined intuition among chess players (De Groot, 1946). Later Simon developed De Groot's ideas about the nature of intuition; he focused on the possibilities of using intuition appropriately. These relied on the acquisition of experience and expert knowledge (Simon, 1987, pp. 55-62). Klein also agrees with this thesis; he emphasises that experience plays an essential role in obtaining good intuitive decisions. Research by Bower, Regehr, and Balthazard (1990) confirmed the affect these factors have on whether intuitive decision-making is good. Intuition is influenced by emotions in addition to knowledge and experience. Shapiro and Spence, also acknowledge this, stating that intuition is an unconscious, holistic information processing regime in which decisions are made without conscious consideration of the rules or consequences, and it enables one to have a good feeling without being able to explain why (Shapiro \& Spence, 1997, p. 64). This approach focuses on the feelings that accompany intuitive decision-making process, and thus determine its direction. The influence exerted by emotions on the intuitive decision-making process is also confirmed by other research (e.g. Löwenstein \& Lerner, 2003; Damasio, 2000). The environment in which the intuitive process takes place is another 
demonstrable factor influencing intuition. Burke and Miller highlight this fact stating that intuition "is a cognitive conclusion based on the culmination of experience and emotional inputs of the decision-maker" (Burke \& Miller, 1999, p. 6). They tackle the need for an analysis of the environment that influences intuition (Burke \& Miller, 1999, pp. 15-16). I have identified the following factors that influence the intuitive decision-making process from the theories discussed above. These are knowledge, experience, emotions and the nature of environment in which the intuitive decision-making occurs.

The term intuition is also dealt with differently in theories of managerial decisionmaking. This could be because intuition is defined both as an outcome and as a process. The definition used by Shapiro and Spence (1997) describes intuition as a process. Burke and Miller see intuition as a cognitive conclusion. Klein adopts a similar position. Hogarth, however, does not differentiate between the process and results, and uses them interchangeably. Consequently Dane and Pratt question whether it is necessary to differentiate between intuitive process (intuiting) and intuitive judgements (Dane \& Pratt, 2007, p. 36). They claim that intuition is an unconscious process involving holistic associations that are quickly produced and which result in emotionally charged decisions (Dane \& Pratt, 2007, p. 36). While the outputs of our intuition are accessible to our consciousness, intuiting is unconscious (Dane \& Pratt, 2007, pp. 36-37). Distinguishing between intuiting and intuition outcomes can help us create a model of intuitive decisionmaking. It can simplify the application of factors that affect intuiting in decision-making, and we can then determine the factors that influence the decision-making process and the phase in which they do so.

There is much inconsistency in the way intuition is understood and defined, but the most exact definition is provided by Sinclair and Ashkanasy. They define intuition as "a non-sequential process of information processing that includes cognitive as well as emotional elements; the outcome of this process is thus immediate understanding without any conscious reasoning" (Sinclair \& Ashkanasy, 2005, p. 357). This definition distinguishes between intuiting and intuitive outcomes and enables us to envisage the factors behind intuition. This makes for a neater definition, enabling us to examine intuition more effectively.

Given the aforementioned findings, we can conclude that intuitive decision-making is a unique approach to information processing. The information is examined in relation to cognitive as well as emotional aspects. The cognitive aspects could be knowledge, experience and evaluating the environment in which intuitive decision-making takes place. The emotional aspects are concrete emotions that influence the entire decision-making process. In the next section, we will examine the influence emotions exert on intuitive decision-making.

\section{From rationality to intuition}

Since the organisation mitigates the tension and chaos caused by limited rationality, paradoxically the use of intuition in decision-making can help the individual. Through the organisation's rules, norms, values and rationally established approaches, it provides the individual with a safe and familiar environment where they do not have to fear the unknown. 
That is why they are able to decide intuitively based on their knowledge and up-to-date experience in the organisation they are familiar with. According to Iva Stuchlíková, intuition can be understood as a form of intellectual process that is separate from conscious thinking and as a process that produces knowledge of a higher quality than explicit thinking does (Stuchlíková, 2005, pp. 9-15). If we look at intuition within the context of human interaction and the social background, then two categories appear that are important to intuitive decision-making. These are knowledge and experience and they constitute the set of factors necessary for making the right decision. In addition to knowledge, another factor is required for decision-making: understanding. This leads us to another category important in intuition: emotions.

Hannah Arendt states that language is the only medium through which spiritual activities can manifest themselves to the outer world and also to the inner "I". No language has a ready-made vocabulary for the needs of inner perception and harmony; we borrow words intended to convey either a sensual experience or other experience from everyday life. We do not borrow these words in an ad-hoc or arbitrarily conventional manner, though. So long as we stay within the boundaries of normal thinking, we need to illustrate our concepts using examples. The situation differs entirely when rationality has to be extended beyond the boundaries of a given world and we enter into the sphere of speculation, where we cannot associate an adequate example with rational concepts. In this case, metaphor comes into play (Arendt, 2001).

Metaphorical communication holds significance for the study of intuitive managerial decision-making because it not only conveys pre-existing knowledge and experience, but also the emotional harmony accompanying the decision. Knowledge and experience are structured in the form of metaphor indicating how pre-existing experience is reflected in decision-making behaviour. If managers ever experience a similar situation, then they assess how similar it is in relation to the current situation. The degree of similarity with the previous experience and the new situation is verified through the managers' knowledge. The emotional tone relating to past experience is manifested in the metaphor. In this way, both platforms of intuitive decision-making are connected-the sphere of knowledge (knowledge and experience) and the sphere of understanding (emotions).

\section{Language, metaphors, and managerial decision-making}

The relationship between emotions and experience is an unconscious process that can be manifested through metaphor. The language used by managers can show how they understand and interpret the world. Metaphor is not mere poetic dexterity or a figure of speech. George Lakoff and Mark Johnson state that the concepts that drive our thinking are not simply a question of intellect, they control our everyday life even down to the smallest detail. Our conceptual system is largely metaphorical (Lakoff \& Johnson, 2002). Thus everything we experience, do, the way we act is translated into language, into the words which express our interpretation of the world around us. When deciding intuitively, managers rationalise their decisions only at the moment they justify their decision, when debating the consequences of their actions. According to Lakoff and Johnson, thoughts and meanings can be understood as objects. Language expressions then become the containers in 
which we try to fit the meaning and value of a thought. Consequently, we send messages via communication. And the conceptual system we use can be seen as metaphorical.

Metaphors are influenced by the managerial discourse that can be studied more easily, for example, through the textual analysis of managerial manuals, as pointed out by Jan Kalenda who uses this method to study social conflict in the workplace (Kalenda, 2013). Discourse analysis is not the most suitable method for examining metaphors, however, since it only takes account of knowledge and experience, ignoring emotions. On the basis of this theoretical research, I decided to research managerial decisions that took account of cognitive turnover in management theory. When is a decision taken? Is it the same in all individuals? How does this affect you? These questions are very much a response to the need to find a new way of investigating this. The decision is a cognitive process occurring inside the manager's head, but we are wholly unable to say exactly when the decision was taken and what effect it has. The language used by managers to explain their decisions or choices justifies their solutions or rationalises their management negotiations. The aim of my research is to describe managers' intuitive decisions through metaphorical statements reflecting knowledge, experience and emotion-the important factors affecting intuitive decision. These also determine the circumstances of the field of knowledge and understanding within executive decisions. Narrowing the effect experience, knowledge and emotions have on intuitive decisions is a deliberate reduction managers to grasp and description of the observed research problem. The description should contribute to the theory on intuitive managerial decisions, especially where we have knowledge on how to rationalise intuitive managerial decisions reflecting knowledge, experience and emotions, and how this is present in the metaphors managers use when rationalising. Such metaphors take account of the factors influencing intuitive managerial decisionmaking; at the same time, the elements from the sphere of knowledge and understanding are revealed. By narrowing the area to the influence exerted by experience, knowledge and emotion on intuitive decision-making the researcher will gain an understanding of the issue and be able to describe it. The initial results of this contextually sensitive research, which take account of the fact that seemingly identical or similar institutions (management) take on a variety of different meanings, indicate that in the interviews with managers there were significant similarities in the conceptual metaphors managers use to explain "how things are done" and significant differences in the conceptual metaphors explaining "how I do it".

Research on metaphor as a reflection of managerial decision-making may, unlike other approaches show the emotional colouring of the final decision. This can be compared to other approaches in the social sciences, for example, ethnomethodology, which takes social interaction into account, and discourse analysis, which concentrates more on the social context. However, emotions influence the decision-making process and it is important that this is accepted in the research. The research could then enhance our understanding of this phenomenon.

Metaphors are an integral part of our natural language. However, a deeper analysis demonstrates that their use is not. This is because they reflect a number of social extralinguistic factors. The most essential of these to managerial decision-making are knowledge, experience and emotions. An exploration of the metaphors used by managers 
when rationalising their intuitive decisions could provide a new perspective on managerial decision-making generally.

The resulting description should contribute to the elaboration of a theoretical concept of intuitive managerial decision-making and enhance our understanding of how knowledge, experience and emotions are expressed in the rationalisation of intuitive managerial decisionmaking, and how this is reflected in the metaphors managers use in rationalisation. The following categorisation of metaphorical communications could provide a new perspective on managerial activity associated with intuition.

Using data obtained from in-depth interviews with top managers, I will categorise the metaphorical expressions managers use when rationalising their intuitive decisions and the consequences of them. I will analyse the interviews as constructing narratives; in other words, I will look at how the managers construct the rationalisation of their intuitive decision as well as the consequences and efficiency of the decision-making process. I have identified the influence of managerial and business discourse which appears in the

Table 1.

\begin{tabular}{|l|l|}
\hline The Metaphors & The Meaning \\
\hline $\begin{array}{l}\text { "I've got five people under my belt, some } \\
\text { directly and approximately fifteen to } \\
\text { seventeen." }\end{array}$ & $\begin{array}{l}\text { An orientation metaphor, what comes below } \\
\text { at the lower level in the organisation system. } \\
\text { A structural metaphor. }\end{array}$ \\
\hline $\begin{array}{l}\text { "If you just have a rock, you can water the } \\
\text { rock, you can add fertiliser, you can do } \\
\text { anything, but flowers will not grow on it, I } \\
\text { have come to the conclusion that I only want } \\
\text { to work in fertile soil, that I want to grow } \\
\text { flowers in fertile soil. If there isn't any fertile } \\
\text { land, just leave." }\end{array}$ & $\begin{array}{l}\text { People are like plants, we have to care for } \\
\text { them, grow them. The ontological metaphor. }\end{array}$ \\
\hline $\begin{array}{l}\text { "... there are about sixty people under me now } \\
\text { and nobody is ..." }\end{array}$ & $\begin{array}{l}\text { An orientation metaphor, what is below at the } \\
\text { lower level in the organisation system. } \\
\text { Orientation metaphors point to spatial } \\
\text { orientation. }\end{array}$ \\
\hline $\begin{array}{l}\text { “... the train does not pass through it ..." } \\
\text { “... cool relations ..." }\end{array}$ & $\begin{array}{l}\text { An ontological metaphor - our experience of } \\
\text { a physical object and substance is a further } \\
\text { basis for understanding. }\end{array}$ \\
\hline $\begin{array}{l}\text { "People are like flowers" } \\
\text { "We have generation x employees, but more } \\
\text { generation y ones - they are such chickens"2 }\end{array}$ & $\begin{array}{l}\text { People are chickens indicates very young } \\
\text { staff. It is an ontological metaphor. }\end{array}$ \\
\hline $\begin{array}{l}\text { "... they want a minimum working time ..." } \\
\text { “.. I despise people ..." }\end{array}$ & $\begin{array}{l}\text { Time is money, people are money, treasure. } \\
\text { An ontological metaphor. }\end{array}$ \\
\hline
\end{tabular}

2 This metaphor corresponds to Czech, in English the primary meaning is not that they are young but that they are scared. 
metaphorical communication of managers. The analytical approach could therefore be seen as a description that is based on an obvious social problem: When managers make intuitive decisions as part of their role, they retrospectively rationalise the reasons for and consequences of their actions. The interview method is an appropriate data-gathering method as the documents available in organisations tell us little about the rationalisation process.

Top managers are an appropriate sample because their decision-making is less bound by standardised decision-making procedures than is commonly the case with middle managers. The number of informants is not crucial in this case. The validity of the qualitative analysis depends on the analysis itself rather than sample size.

Initial research findings: In the interviews, managers explained how they had made their past choices. They explained why they made that particular choice. After a few interviews, differences began to emerge, particularly in the metaphor used when referring to making decisions about the organisational system and formal strategy and decisions about people, staff or team members. In the case of formal matters based on a set organisational system, they used metaphors that are already firmly established and used in the culture to explain their actions. In making decisions about people, they turned to emotions and considered explanation to be more important than in the first case. They used more recent metaphors reflecting their value orientation and emotions. They sought to explain their decisions so as to be understood by others. In addition to knowledge (knowledge, experience), there is a need for understanding (emotion). Examples of the differences in the use of metaphor when explaining decisions are given in Table 1 .

\section{Conclusion}

Metaphorical communication reflects knowledge and emotions. For example, love or hatred for people is one emotional scale along which managers' action in terms of different values. Their decisions differ partly because of this category. This was mainly reflected in staffing decisions. For example, you can say who the manager is willing to work with and who not. This difference could also be seen in the dismissal of employees. Conversely, commonly used metaphors are associated with decisions that rely on a formal organisational mechanism or a set and applied company strategy.

If managers use metaphors to explain decisions based on the organisational system and established practice, then they use common metaphors, grounded in language and culture. The manager also relies on explicit knowledge. That helps him to explain his actions. In situations where managers need to discuss a decision that differs to the established practice, they rationalise their actions, usually turning to emotions and their own personal focus. In this case, they more often use metaphors that are not common but are created for a particular situation, a particular person. These metaphors rely on unconscious tacit knowledge. An effort is obviously being made to give a better explanation. Some examples can be seen in the tables below.

The tables show that the managerial discourse is supplemented by meanings and explanations of why such decisions were taken concerning co-workers and subordinate employees. At the same time, it is a decision the manager has taken deliberately, with a certain aim in mind, but not on a rational basis. The decision was acted upon and then 
Table 2.

\begin{tabular}{|l|l|}
\hline Commonly used metaphor & Meaning of metaphor \\
\hline $\begin{array}{l}\text { "A man can always see a point somewhere in } \\
\text { front of him." }\end{array}$ & Objectively stated goal. \\
\hline "I met some people who showed me the way." & Method of reaching a goal. \\
\hline "At the higher level of management." & Organisational hierarchy. \\
\hline "I am surveying the labour market." & Labour market focus. \\
\hline "Key positions." & Important positions in the organisation. \\
\hline "To spend time with them..." & Time is money. \\
\hline "I am under pressure." & Many problems to be solved. \\
\hline
\end{tabular}

Table 3

\begin{tabular}{|l|l|}
\hline Metaphor & Meaning of metaphor \\
\hline $\begin{array}{l}\text { "This person is loyal, hardworking and } \\
\text { introduces good chemistry into this team." }\end{array}$ & Reason for choosing a team member. \\
\hline $\begin{array}{l}\text { "It is very difficult to teach adult people to } \\
\text { eat with a fork and spoon." }\end{array}$ & Explanation for exchanging co-workers. \\
\hline $\begin{array}{l}\text { "But it is like a futile marriage argument } \\
\text { which has no place in management." }\end{array}$ & Solving a conflict without rational arguments. \\
\hline
\end{tabular}

rationalised. It was important for the manager to explain his decision, because he relied not only on his knowledge and experience, but also on emotions and the value system. The next steps in the research will ultimately explain the employee's language profile in management discourse. It will explore the use of metaphor in verbalising managerial decisions. The data set based on the interviews with the managers will be supplemented by the written interpretations of the managers about the characteristics of the employees and the employees.

\section{References}

Arendtová, H. (2001). Jazyk a metafora. Metafora a nevyslovitelné. [Language and metaphor]. In Život ducha I. Díl-Myšlení (pp. 112-140). Praha: Aurora.

Bower, K. S., Regehr, G., \& Balthazard, C. (1990). Intuition in the context of discovery. Cognitive Psychology, 22, 72-110.

Burke, L. A., \& Miller, M. K. (1999). The academy of management executive (1993-2005). Themes: Structure and desicion making, 13(4), 91-99.

Collins, H. (2010). Tacit and explicit knowledge. Chicago: The University of Chicago Press. 
Damasio, A. R. (2000). Descartesův omyl: emoce, rozum a lidský mozek [Descartes’ error: Emotion, reason, and the human brain]. Praha: Mladá fronta Kolumbus.

De Groot, A. D. (1946). Het denken van den schaker:_Een experimenteel-psychologische studie. Amsterdam: Noord-Hollandsche Uitgevers Maatschappij.

Epstein, S. (2003). Cognitive-experiential self-theory of personality. In T. Milton \& M. Lerner (Eds.), Comprehensive handbook of psychology. (Vol. 5, Personality and social psychology (pp. 159-184)). Hoboken, NJ: Wiley.

Gigerenzer, G. (2008). Why heuristics work. Perspectives on Psychological Science, 3, (1), 20-29.

Gigerenzer, G., \& Selten, R. (2001) Bounded rationality: The adaptive toolbox. Cambridge, Mass.: MIT Press.

Gigerenzer, G., \& Selten, R. (2002). What is bounded rationality. In Bounded rationality: The adaptive toolbox. Massachusetts: Institute of Technology.

Gigerenzer, G., \& Gaissmaier, W. (2011). Heuristic decision making. Annual Review of Psychology, 62(1), 451-82.

Hogarth, R. M. (2001). Educating intuition. Chicago: The University Chicago Press.

Chase, W. G., \& Simon, H. A. (1973). Perception in chess. Cognitive Psychology, 4, 55-81.

Kahneman, D. (2012). Myšlení, rychlé a pomalé [Thinking, fast and slow]. Brno: Jan Melvil Publishing.

Kahneman, D., \& Klein, G. (2009). Conditions for intuitive expertise: A failure to disagree. American Psychologist, 64(6), 515-26.

Kalenda, J. (2013). Personální management a sociální konflikty: analýza diskursu. [Personal management and social conflict: discourse analysis]. In D. Lužný a kol. Sociální konflikty. Sociologická a andragogická perspektiva (pp. 69-87). Olomouc: UP v Olomouci - Filozofická fakulta.

Klein, G., \& Klinger, D. (1991). Naturalistic decision making. Human System IAC GATEWAY, 2(1), $16-25$.

Klein, G. A. (1993). Decision making in action: Models and methods. Norwood, N.J.: Ablex Pub.

Klein, G. A. (2003). Intuition at work: Why developing your gut instincts will make you better at what you do. New York: Currency/Doubleday.

Klein, G. A. (2009). Streetlights and shadows: Searching for the keys to adaptive decision making. Cambridge, MA: MIT Press.

Klein, G. A. (2015). A naturalistic decision making perspective on studying intuitive decision making. Journal of Applied Research in Memory and Cognition, 4(3), 164-168.

Lakoff, G., \& Johnson, M. (2002). Metafory, kterými žijeme. [Metaphors we live by]. Brno: HOST.

Löwenstein, G., \& Lerner, J. S. (2003). The role of affect in decision making. In R. Davidson, H. Goldsmith, \& K. Scherer (Eds.), Handbook of affective sciences (pp. 619-642). Oxford: Oxford University Press.

Merton, R. K. (2007). Studie ze sociologické teorie [Social theory studies]. Praha: SLON.

Robbins, S. P., \& Coulter, M.K. (2004). Management. Prentice Hall.

Shapiro, S., \& Spence, M. T. (1997). Managerial intuition: A conceptual and operational framework. Business Horizons, 40(1), 63-92.

Silverman, D. (2005). Ako robit kvalitatívny výskum: praktická príručka. [Doing qualitative research]. Bratislava: Ikar.

Simon, H.. A. (1979). Rational decision making in business organisations. American Economic Review, 69, 493-513.

Simon, H. A. (1986). Rationality in psychology and economics. Journal of Business, 59(4), 209224.

Simon, H. A. (1987). Making management decisions: The role of intuition and emotion. Academy of management EXECUTIVE, 1(1), 57-64. 
Simon, H. A. (1987a). Using cognitive science to solve human problems. In F. Farley \& C. H. Null (Eds.), Using psychological science: Making the public case. Washington, DC: The Federation of Behavioral, Psychological and Cognitive Sciences.

Simon, H. A. (1992). What is an explanation of behaviour? Psychological Science, 3(3), 150-161.

Sinclair, M., \& Ashkanasy, N. M. (2005). Inutition: Myth or a decison-making tool? Management Learning, 36(3), 353-370.

Stuchlíková, I. (2005). Implicitní znalosti a intuitivní pojetí v pedagogické praxi. [Implicit knowledge and intuitive approach in the pedagogical praxis]. In V. Svec (Ed.), Od implicitních teorií výuky k implicitním pedagogickým znalostem (pp. 9-15). Brno: Paido.

Tversky, A., \& Kahneman, D. (1974). Judgment under uncertainty: Heuristics and biases. Science, 185(4157), 1124-1131.

Department of Sociology, Andragogy and Cultural Anthropology

Faculty of Arts,

Palacky University,

Tr. Svobody 26,

77900 Olomouc,

Czech Republic

Email: veronika.gigalova@upol.cz 